\title{
Learning Electricity using Arduino-Android based Game to Improve STEM Literacy
}

\author{
Alifa Irna Yasin ${ }^{1}$, Eka Cahya Prima ${ }^{*}$, Hayat Sholihin ${ }^{2}$ \\ ${ }^{1}$ Department of Science Education, Faculty of Mathematics and Science Education, Universitas Pendidikan Indonesia, Indonesia \\ ${ }^{2}$ Department of Chemistry Education, Faculty of Mathematics and Science Education, Universitas Pendidikan Indonesia, Indonesia \\ *Corresponding Author. ekacahyaprima@upi.edu
}

\begin{abstract}
The STEM is an interdisciplinary approach provided learning atmosphere where students can use science, technology, engineering and math in daily life. The aim of the STEM is educating the students to be STEM Literate. This research goal was to implement STEM learning on electricity using Arduino-Android Game based experiment to 8th-grade students. STEM Learning was chosen as an approach in this research by the consideration that it was developed through Android Game, YWRobot, and Arduino Uno experiment lesson plan and worksheet. The analysis of this research was focused on the effect of STEM learning implementation through lesson plan and worksheet to 8th-grade students' STEM Literacy on electricity topic. The method used in this research was pre-experimental with one group pretest-posttest design. The data of this research was obtained from the STEM Literacy objective test (pretest and posttest) based on Allan Zollman. Then the data were analyzed based on each aspect of STEM Literacy such as science, technology, engineering, and mathematics. The result shows that the value of $\mathrm{g}^{-}$from students' STEM Literacy pretest-posttest are $-0.06,-0.12,-0.06,-0.87$ for science, technology, engineering and mathematics literacy respectively. The result implies that STEM Learning implementation was less optimal to improve science, mathematics, technology and engineering literacy. The reason was because STEM Learning implementation was not implement in continuously. Therefore, science, technology, engineering, and technology literacy regarding electricity topic are emphasized less optimally.
\end{abstract}

Keywords STEM Learning, STEM Literacy, Android Game, Arduino Uno, Electricity

\section{INTRODUCTION}

Education in every country should follow the current development to face competition in various areas of life especially science and technology aspects. The 21 st century is a century of technology, where several countries have implemented many policies which related to scientific education (Lou, Shih, Diez, \& Tseng, 2011). Many scholars argued that the integration of science, technology, engineering and mathematics (STEM) education have the advantage to the national economy, teachers, and institutes which have been working to develop this STEM education program (Tseng, Chang, Lou, \& Chen, 2013). STEM education provides knowledge and skills that are transferable to the future problem and can help them to approach college and their career (Laboy-Rush, 2011). It coherent with the goal of IGCSE curriculum such as help the students to understand about scientific theories and method work together, the study of practice of science is affected and limited by social, economic, technology, ethical and cultural factors, the application of science in everyday life may be both helpful and harmful to the environment and the last knowledge that science overcomes national boundaries (Cambridge International Examinations, 2013). By implementing STEM education, the researchers believed that students can study mathematics and science and to consider their careers in engineering, science, and technology in the future (Prima, Oktaviani \& Sholihin, 2018).

The STEM is considered as instructional strategies, teaching method, interdisciplinary approach and part of the curriculum. Bybe (2013) argued that STEM is an approach functioned as a tool for facilitating students become STEM literate. It can be stated that the goal of the STEM is creating STEM-literate students. In line with Reeve (2013) that the goal of STEM approach is providing learning atmosphere where the students can use science, technology, engineering, and math in daily life context that

Received: 29 June 2018

Revised: 30 July 2018

Published: 31 July 2018 
can be connected it into certain occupation and surround environment until STEM-literate students who can compete in the knowledge-based economy.

The term STEM is derived from Science, Technology, Engineering, and Mathematics. STEM education integrates the four disciplines through cohesive and active teaching and learning approaches (Ong, Mclean, \& Greco, 2014). Bybee (2013) stated that STEM education focused on designing a solution for real-world issues and problem. Bybee (2013) also added that it is an educational approach to conduct science and engineering practices combining several strategies that provide an implementation of crosscutting concepts and core disciplinary ideas in science lessons. STEM is aimed to critic and support nowadays education reform. It is adapted from common international standard to prepare better teacher and enhance coordination across the whole K-12 education system.

STEM as an approach provides active learning activity which beneficial for both students and teacher. STEM pointed on a multidisciplinary approach, including inquiry and problem-solving to prepare students in STEM subject and increase the number of post-secondary graduates who are prepared for STEM occupations (National Research Council, 2013). This STEM education is argued to improve the proficiency of all students in the STEM which in line with 21 st-century skills such as critical thinking, problemsolving, creativity, collaboration, self-directed learning, and scientific, environmental and technological literacy. Specifically, five domains have been proposed for promoting STEM involvement including; interest and engagement; competence and reasoning; attitude and behavior; career knowledge and acquisition; and content knowledge (Prima, Oktaviani \& Sholihin, 2018). Moreover, integrating STEM subject can be engaging for students can promote problem-solving and critical thinking skills to solve a real-world problem.

In recent years, the STEM becomes a trending pedagogic topic in every education scoop in many countries. The interest of researchers in the transformation of game-based learning technology, especially in STEM education is growing rapidly. Meluso, Zheng, \& Lester (2012) stated that science content learning and self-efficacy of the students which taught through the STEM and gamebased learning significantly increased. Rapini (2012) argued that the games "World of Goo" will help the player to understand the topic of static equilibrium.

Nowadays, learning science with Arduino becomes the interesting discussion. Arduino or microcontroller is the device that can control how the component in the circuits are connected or disconnected independently. Huang (2015) argued that providing students with exposure to Arduino and open-source is able to enhance physics classroom beyond the traditional book problems and traditional demonstration labs. One of the example projects which commonly done with Arduino is traffic light. Arduino can be programmed by the software and control light intensity. Carro, et al., (2014) added that "The Color of Light" project with Arduino is able to generate students' curiosity and allow the teacher to emphasize the technology of LED in daily life.

The subject which commonly taught by using STEM approach is Physics. Suwarma, Astuti \& Endah (2015) argued that "Balloon Powered Car" as a teaching media to deliver linear motion topic could increase students' motivations and achievement in the final examination, and gave engineering learning experience. Anwari, et al., (2015) shows that STEM education approach in learning magnetism, electricity and electrical energy is able to attract students' interest in science, provide deep and meaningful learning, and improve students' thinking and practical skills. Afriana, Permanasari \& Fitriani (2016) reported that project-based learning integrated with the STEM in experimental is significantly enhanced students' scientific literacy in learning pollution. Moreover, Carro, et al., (2014) suggested that the use of Arduino Uno as a smart device is able to generate discussion among the students and enhance curiosity of students.

STEM education has a close relation with STEM Literacy. According to Bybee (2013), one of the global challenges which faced by STEM education is developing STEM Literacy as an aim and the identification of new learning outcomes, curriculum programs, and teaching practice. Currently, there is not a standard or particular agreement from any professional education organization which clarifies the definition of STEM Literacy. One of the researchers of STEM Literacy, Zollman (2012) developed a deictic description of STEM Literacy in three strata. The first stratum is literacies of science, technology, engineering and mathematics which commonly stated as four STEM strands. The four strands of STEM Literacy are presented in the following explanations. (a) Science Literacy is defined as the ability of students to use and process to understand scientific knowledge such as physics, chemistry, biology and earth and space science. (b) Technology Literacy is defined as the ability to operate and demonstrate technology effectively and productively to conduct research and solve the problem collaboratively. (c) Engineering Literacy is defined as the ability to apply scientific and mathematics principal systematically and creatively to utilize practical ends. (d) Mathematics Literacy is defined as the ability to identify, understand and engage in mathematics to think creatively about solving problems.

One of the topics on the STEM which makes confusion to the students is electricity. Students considered that physics as one of the most prevailing and problematic subjects in the realm of the subject which caused their low motivation and negative attitude towards learning (Guido, 2013; Prima, Putri, \& Rustaman, 2018). The problems of learning electricity have been found by the previous works 
(Prima, Putri \& Sudargo, 2017). Mulhall, McKittrick \& Gunstone (2001) stated that Electricity is a problem, as it involves extremely complex and highly abstract concepts and is thus totally dependent on models/ analogies/ metaphors. Cao and Brizuela (2016) also added that the students are hard to explain the role of the electric field in the interplay of the different elements of a circuit. There was also an alternative conception about electric current in the electric circuit which generated by the students. According to Samsudin, et al., (2016) most students think that current flow fast because of turning on or off the switch of the lamp, they didn't even realize about drift speed of current and electric dipole. To handle these students' problems on investigating the electrical concept and application, the novel STEM learning using ArduinoAndroid Game based experiment will be first proposed.

According to the background, this research aimed to improve students' STEM literacy in electricity by applying STEM Learning using Arduino-Android Game Based Experiment. This prior research will be conducted by designing and analyzing the lesson plan, the worksheet, and the test instrument of STEM Literacy on electricity implemented to 8th-grade students.

\section{METHOD}

Experimental research is used as the method of this research. Pre-experimental Design is chosen as one of the experimental research methods to discover a causal relationship only by involving one group of the subject. In other words, this method is used when there is no control group or extraneous factors which can influence internal validity (Fraenkel, Wallen \& Hyun, 2011). Extraneous factors are any influences in selecting participants, the producers, the statistics, or the design likely to affect the outcome and provide an alternative explanation for the result than what its expected (Creswell, 2012). In this research, the pre-experimental design was used to discover the effect of STEM Learning approach implemented by the researcher to students' STEM Literacy. Therefore, the researcher will know whether any change occurred due to the implementation of STEM Learning approach in learning electricity.

The design of this research was One-Group PretestPosttest Design. A pretest was used to measure some attribute or characteristic of participants in an experiment before receiving treatment. While posttest was used to measure some attribute or characteristic of participants in an experiment after receiving treatment (Creswell, 2012).

Table 1 One group pretest and posttest design

\begin{tabular}{ccc}
\hline Pre-test & Implementation & Post-test \\
\hline STEM Literacy - & Implementation of & STEM Literacy - \\
Based Electricity & STEM learning & $\begin{array}{c}\text { Based Electricity } \\
\text { Pretest }\end{array}$ \\
\hline
\end{tabular}

In this research design, the ability of students' STEM Literacy was measured before and after the implementation of STEM learning. A diagram of this design was explained in Table 1.

The location of this research was one of the Private Junior High School, which is located in Bogor, West Java. Because this school applied the IGCSE curriculum in the teaching-learning activity. The population of this research would be all 8th students. The samples in this research were one class, which consist of 16 students from the 8th grade at X Private Junior High School. This class consisted of 7 female and 9 male students who were 15 years old. According to the index of student's achievement from school, this class consisted of students who categorized as medium achiever from the other two classes.

In order to avoid misconception about this research, some operational definitions are explained in this research. Those terminologies are explained as follow: Science, Technology, Engineering and Mathematics (STEM) is an approach used to teach science and mathematics applications through engineering activities that involve the development of technology. STEM approach is the independent variable in this research which implements in the class. The STEM approach which implemented in learning electricity is described in the lesson plan that has been arranged. STEM Learning implementation in this research is investigated through an observation sheet. Moreover, STEM Literacy is the ability to identify, apply, and integrate concept from science, technology, engineering, and mathematics to understand complex problems and to innovate to solve them. STEM literacy is the dependent variable in this research which the result depends on the implementation of the STEM approach in learning electricity. In this research STEM Literacy of the students is investigated through STEM Literacy instrument test.

In this research, the instrument is necessary to gain the data. There are several types of research instrument used in this research. Those instruments are described as follow: Observation sheet was used to measure the implementation of STEM learning in the class. The observation sheet contained the steps which conducted by the researcher and the students that will be assessed whether it is implemented appropriately or not. The objective test is the instrument which used to test students' STEM Literacy. In this research, a STEM Literacy based test which covers the four aspects such as Science, Technology, Engineering and Mathematics in electricity topic used as an objective test. This test was used in both pretest and posttest. The pretest was given before conducting the treatment to know STEM Literacy basic of students. While posttest was given to know the improvement of students' STEM Literacy. The type of question of pretest and posttest was multiple choice, which contained 27 questions. The multiple choice questions 


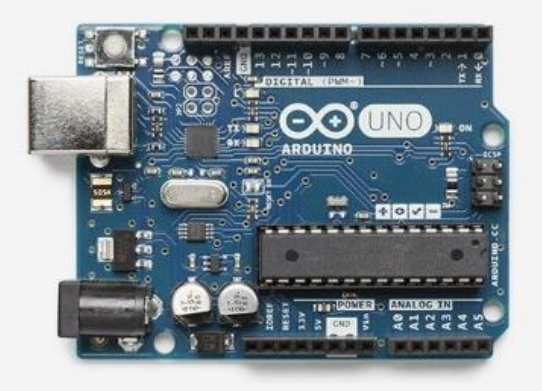

Figure 1 Aduino uno (Source : store-usa.arduino.cc)

were constructed based on the four strands of STEM Literacy from Zollman (2012).

The objective test used in this research was tested before it was used as pre-test and post-test. The instrument developed started by analyzing the four STEM aspects and indicators which suitable for the concept of electricity. Then the researcher formulated and arranged the objective test. In the preparation stage, the objective test was validated and tested to the students who have learned about electricity, which is 10th-grade students. The analysis of objective test which used in this research consisted of the discriminating power, distractor, and level of difficulty, validity, and reliability.

The content of electricity that is used in this research is limited by Cambridge IGSCE Syllabus on Physics 0625 for examinations 2016 on competence 4.2 about Electrical Quantities and competence 4.3 about Electrical Circuits. Moreover, Arduino Uno is known as a small microcontroller board with USB plug which can connect into PC, laptop or even directly to electricity sources. Arduino or microcontroller as shown in Figure 1 is the device that can control how the component in the circuits are connected or disconnected independently. The control command can be controlled from a computer or programmed by the computer using Arduino's Software. The name of Arduino is given by the original makers

Welcome to

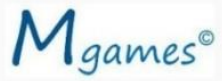

\section{ELECTRICAL CIRCUITS}

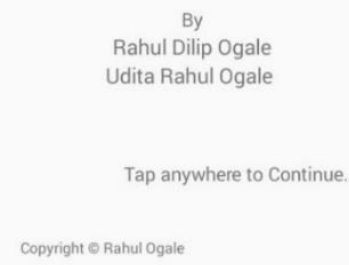

Figure 3 MGames science welcoming screen (Sources: MGames Science)

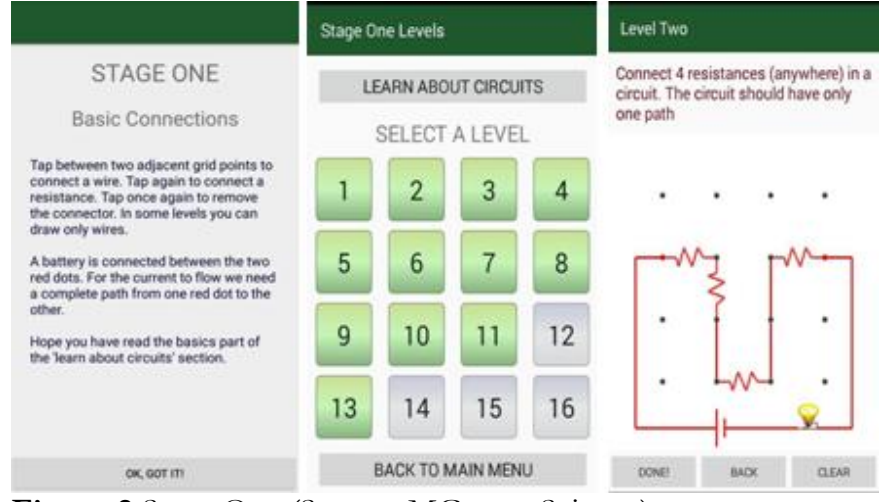

Figure 2 Stage One (Source: MGames Science)

(Monk, 2010). There's also the clone of Arduino design which often used "druino" as the last name of the design such as Freeduino or DFRduino.

According to Funduino (2016), there are different size of board that can be used with the Arduino software. The official name of the board is "Arduino", this board is cheaper than others but still an equivalent Arduino. Officially the board of the Arduino that mostly used is Arduino UNO, Arduino MEGA, Arduino Mini, etc. The Software or program that needed to control the Arduino is "Arduino". This Software or program available for MAC, PC, and Linux. It can be can freely download it from www.arduino.cc.

In this research, the Arduino or microcontroller is added as the component of the circuit that should be built by the student. The Arduino will be programmed by the software and control the light that will turn on in the circuit. In this case, the student will be asked to make a prototype of the traffic lights that can be modified by them self.

Android Game: MGames Science as shown in Figure 2 is logic games puzzle and science games. It is developed by Rahul Dilip Ogale and Udita Rahul Ogale and published in 4th August 2016. It is $3.2 \mathrm{MB}$ game and can be download in Google Play Store and apkpure.com.

Mgames is an innovative way to learn science through the science game. It will help the users to learn how to make a circuit (series and parallel), find the effective resistance for a given circuit, and calculate the current. Moreover, there is introductory material about series and parallel circuits, Ohm's law, and resistance in combination circuits. Therefore, the users can read it before playing the game. Mgames consists of four stages and one free mode stage. In each stage, there will be 12- 20 levels which should be passed by the users. If the answer is wrong, the next level can't be opened. For example, in the first stage, as shown in Figure 3, by the following instruction, the game will ask to connect a wire and adding resistance in the given circuit by tapping two adjacent grid point. 


\section{RESULT AND DISCUSSION}

\subsection{Lesson Plan Applied to STEM Learning}

\section{Constructing a STEM Learning Lesson Plan}

In this research, STEM Learning is used as an approach to conducting the teaching-learning activity. Therefore, the lesson plan is constructed as an instrument to measure the implementation of STEM Learning. There are the stages in constructing lesson plan, such as analyzing the curriculum, physics topics, and organizing learning activity which appropriate with STEM Learning. The explanation of those three stages are described as follow:

Curriculum Analysis

2013 National curriculum and Cambridge IGCSE curriculum are analyzed to select a curriculum that supports the implementation of STEM Learning. Cambridge curriculum is more able to provide better scientific understanding, life-long skill using technology and applying multidiscipline subject in daily life. Moreover, that objective is in line with the purpose of STEM Learnings which is developing students' understanding through scientific practices in other to solve the real-world problem by crosscutting science ideas and technology.

Physics Topics Analysis

After choosing Cambridge IGCSE curriculum, the content of physics for $8^{\text {th }}$ grade is determined. The researcher selects the topic of electricity and subtopics of electrical quantities and an electrical circuit. Thus, it will be adequately proper with MGames Science (electricity) and Arduino Uno which used in this research.

Organizing Learning Activity

The lesson plan doesn't not only consists of delivering the topic of electricity as stated in learning objective but also shows the approach used in the class. The approach used in this research is STEM Learning adopted from Jolly (2014). Therefore, the lesson plans are developed through the topic of electricity and adjusted with the approach of STEM Learning. MGames Science and Arduino Uno experiment are chosen as a learning activity because both

Table 2 Summary of STEM learning lesson plan

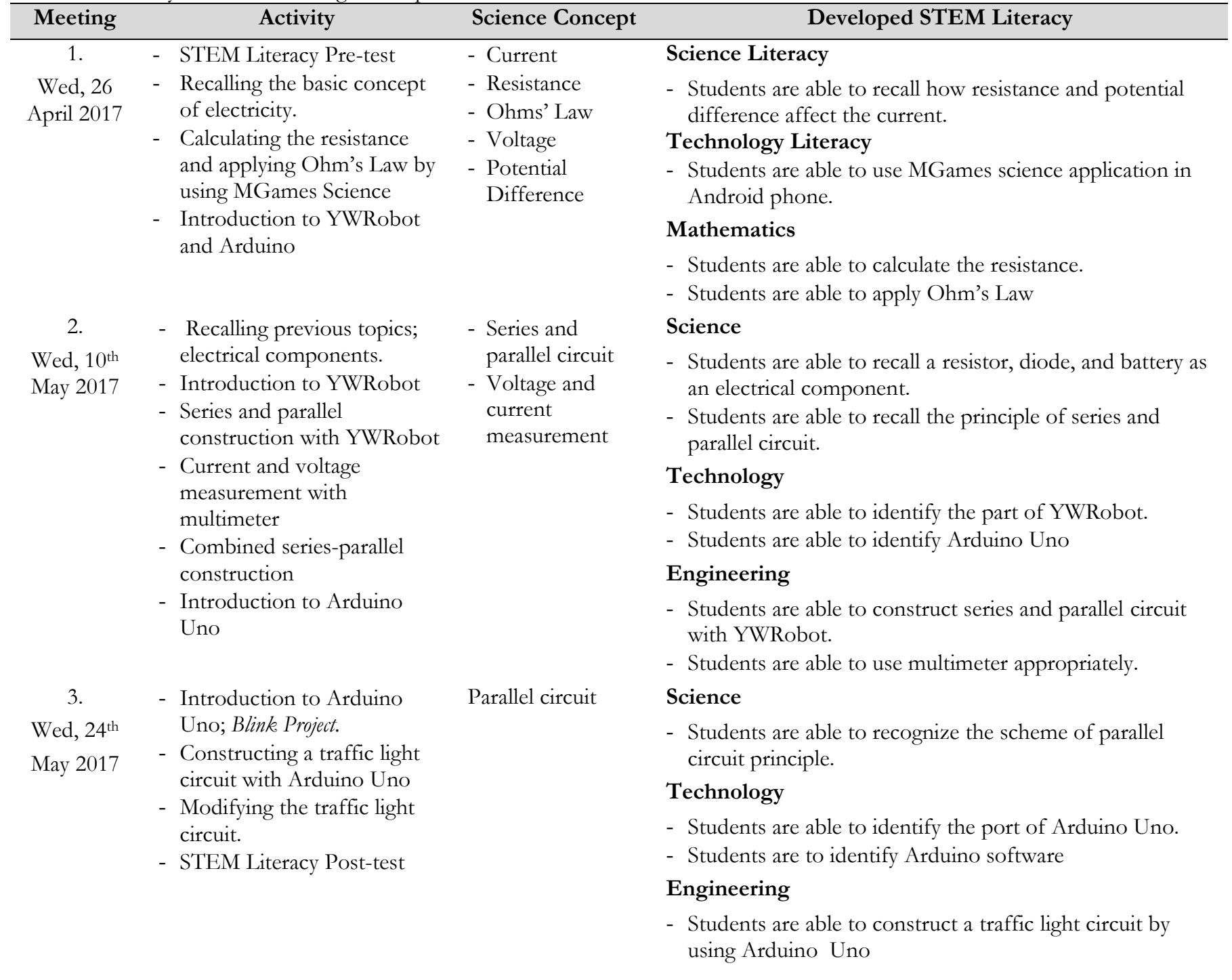


experiments can be engaged with the topic of electricity and adequately adjusted with STEM Learning approach.

After that three-stage finished, the lesson plans are constructed in three meetings to develop each of the STEM Literacy aspects. The full version of three lesson plans used in $8^{\text {th }}$-grade physic students is available in the attachment. While the summary of those three meetings is explained as tabulated in Table 2.

From Table 2, it can be seen that each meeting doesn't emphasize all STEM Literacy aspects. STEM Literacy aspects are delivered separately in three meetings. While STEM Learning is mostly implemented in all meetings. STEM Learning which developed by Jolly (2014) in those three meetings could be described as follow:

Involve Students in Productive Teamwork

In every meeting, the students had to work collaboratively in the group to solve each problem provided in MGames Science application, series-parallel construction with YWRobot and a traffic light project with Arduino Uno.

\section{Hands-On Inquiry and Open-Ended Exploration}

In the first meeting, students are asked to use MGames Science application. In each level of the game, the students are required to tap and type the result and directly submit the answer. The game will give the response directly, if their answer right, the game will lead the students to the next level. While if they fail, the students will not be able to continue to the next level.
For the second and third meeting, Students are required to construct series and parallel circuits by connecting manually jump wire or resistor and lamps into protoboard and YWrobot or Arduino Uno. Moreover, students are asked to modify their circuit without making the lights off. Having Multiple Right Answer and Reframe Failure as Part of Learning

MGames Science used in the first meeting has four levels which will challenge the students. One of level in the games is "constructing resistor path" will require students to try and check their connecting path scheme in MGames Science application. Therefore they might have multiple right answers and experienced the failure.

In the second meeting, students are asked to create a series and parallel circuit. While in third meeting students are asked to construct a traffic light circuit which more advanced than the previous experiment. A student may find an obstacle in constructing and modifying the circuit such as failure to connect jump wire and resistor into protoboard or port in Arduino Uno correctly which make the circuit can't perform well. But, the students are asked to find and try an alternative solution by themselves. Therefore, the students will more understand to solve the problem.

Apply Math And Science Content

Almost all levels in MGames Science application used in the first meeting have required the students to calculate resistance, voltage, and current by using Ohms' Law.

Table 3 The result of observation sheet during STEM learning implementation

\begin{tabular}{|c|c|c|c|c|c|c|c|c|c|}
\hline \multirow{2}{*}{ Meeting } & \multirow{2}{*}{ Activity } & \multicolumn{4}{|c|}{ Observer } & \multicolumn{4}{|c|}{ Score } \\
\hline & & $\mathbf{T}$ & $\mathrm{S}$ & $\mathbf{T}$ & $\mathrm{S}$ & $\mathbf{T}$ & $\mathrm{S}$ & $\left(\frac{\mathrm{Rs}}{\mathrm{Ms}} \times 100 \%\right)$ & Category \\
\hline \multirow[t]{3}{*}{1} & Introduction & $\sqrt{ }$ & $\sqrt{ }$ & $\sqrt{ }$ & $\sqrt{ }$ & $\sqrt{ }$ & $\sqrt{ }$ & 83 & Less \\
\hline & $\begin{array}{l}\text { Recalling previous materials: how current is } \\
\text { affected by resistance and the potential difference }\end{array}$ & $\sqrt{ }$ & $\sqrt{ }$ & $\sqrt{ }$ & $\sqrt{ }$ & $\sqrt{ }$ & $\sqrt{ }$ & & \\
\hline & Applying Ohm's Law by using MGames Science & $\sqrt{ }$ & $\sqrt{ }$ & $\sqrt{ }$ & $\sqrt{ }$ & $\sqrt{ }$ & $\sqrt{ }$ & & \\
\hline \multirow{5}{*}{$\begin{array}{c}\text { Max } \\
\text { Score; } 36 \\
2\end{array}$} & Raw Score & \multicolumn{2}{|c|}{10} & \multicolumn{2}{|c|}{10} & \multicolumn{2}{|c|}{10} & & \\
\hline & Recalling previous materials :electrical components & $\sqrt{ }$ & $\sqrt{ }$ & $\sqrt{ }$ & $\sqrt{ }$ & $\sqrt{ }$ & $\sqrt{ }$ & 100 & Complete \\
\hline & Introduction to Ywrobot & $\sqrt{ }$ & $\sqrt{ }$ & $\sqrt{ }$ & $\sqrt{ }$ & $\sqrt{ }$ & $\sqrt{ }$ & & \\
\hline & Team and Placement & $\sqrt{ }$ & $\sqrt{ }$ & $\sqrt{ }$ & $\sqrt{ }$ & $\sqrt{ }$ & $\sqrt{ }$ & & \\
\hline & $\begin{array}{l}\text { Series and parallel circuit construction with } \\
\text { Ywrobot }\end{array}$ & $\sqrt{ }$ & $\sqrt{ }$ & $\sqrt{ }$ & $\sqrt{ }$ & $\sqrt{ }$ & $\sqrt{ }$ & & \\
\hline $\begin{array}{l}\text { Max Score; } \\
42\end{array}$ & Raw Score & & & & & & & & \\
\hline 3 & Recalling previous materials : Arduino Uno & $\sqrt{ }$ & $\sqrt{ }$ & $\sqrt{ }$ & $\sqrt{ }$ & $\sqrt{ }$ & $\sqrt{ }$ & 100 & Complete \\
\hline & Team and Placement & $\sqrt{ }$ & $\sqrt{ }$ & $\sqrt{ }$ & $\sqrt{ }$ & $\sqrt{ }$ & $\sqrt{ }$ & & \\
\hline & Introduction to Blink Project with Arduino Uno & $\sqrt{ }$ & $\sqrt{ }$ & $\sqrt{ }$ & $\sqrt{ }$ & $\sqrt{ }$ & $\sqrt{ }$ & & \\
\hline & Traffic light project with Arduino Uno & $\sqrt{ }$ & $\sqrt{ }$ & $\sqrt{ }$ & $\sqrt{ }$ & $\sqrt{ }$ & $\sqrt{ }$ & & \\
\hline & Modifying circuit & $\sqrt{ }$ & $\sqrt{ }$ & $\sqrt{ }$ & $\sqrt{ }$ & $\sqrt{ }$ & $\sqrt{ }$ & & \\
\hline \multirow{3}{*}{$\begin{array}{l}\text { Max Score; } \\
36\end{array}$} & Post-test & $\sqrt{ }$ & $\sqrt{ }$ & $\sqrt{ }$ & $\sqrt{ }$ & $\sqrt{ }$ & $\sqrt{ }$ & & \\
\hline & Raw Score & \multicolumn{2}{|c|}{12} & \multicolumn{2}{|c|}{12} & \multicolumn{2}{|c|}{12} & & \\
\hline & \multicolumn{3}{|l|}{ Average Score } & & & & & \multicolumn{2}{|c|}{94.3} \\
\hline
\end{tabular}


Therefore this game strengthens the topic of electricity to students.

In the second meeting, students are not required to calculate but to prove the principle of current and voltage in series and parallel circuit. The students need to find whether series or parallel which have the same current flow and prove whether the theory of the series-parallel circuit is coherent with experiment. The last, in the third meeting students, are required to remember the structure of the parallel circuit.

Learning Activity is Guided by Engineering Design Process

In the second meeting, the students are required to measure both current and voltage in series and parallel circuit. The students have to know how to set and operate

Table 4 Content summary of STEM learning worksheet

\begin{tabular}{|c|c|c|}
\hline No & Worksheet & Questions \\
\hline 1 & $\begin{array}{l}\text { MGames } \\
\text { Science } \\
\text { Experiment }\end{array}$ & $\begin{array}{l}\text { Part } 1 \\
\text { 1. How is currently produced in this circuit? } \\
\text { 2. How does Ohm's law mention about the } \\
\text { circuit? } \\
\text { 3. How does Ohm's law mention about the } \\
\text { circuit? } \\
\text { 4. What are the differences between series and } \\
\text { parallel circuit? } \\
\text { 5. How do you calculate the resistance of series } \\
\text { and parallel circuit } \\
\text { Part } 2 \\
\text { 1. Stage } 1 \text {, connecting the circuit path. } \\
\text { 2. Stage 2, calculate the total of resistance. } \\
\text { 3. Stage } 3 \text {, Arranging resistors based on the } \\
\text { total of resistance. } \\
\text { 4. Stage 4, Applying Ohm's Law to calculate } \\
\text { voltage, current, and resistance. }\end{array}$ \\
\hline 2 & $\begin{array}{l}\text { YWRobot } \\
\text { Experiment }\end{array}$ & $\begin{array}{l}\text { 1. Measuring Voltage and Current in the } \\
\text { Working Circuit (Series Circuit) } \\
\text { 2. Measuring Voltage and Current in the } \\
\text { Working Circuit(Parallel Circuit) } \\
\text { 3. Build your own circuit (Series Circuit with } \\
\text { two lamps) } \\
\text { 4. Build your own circuit (Combined Series and } \\
\text { Parallel Circuit) }\end{array}$ \\
\hline
\end{tabular}

\begin{tabular}{ll}
$\begin{array}{l}\text { Science } \\
\text { Concept }\end{array}$ & \multicolumn{1}{c}{ Developed STEM Literacy } \\
\hline Current & Science \\
Resistance & - Students are able to recall how current is \\
Voltage & $\begin{array}{l}\text { affected by resistance and potential } \\
\text { Ohms' } \\
\text { Law }\end{array}$
\end{tabular}

Technology

- Students are able to use MGames science application in the android phone.

\section{Mathematics}

- Students are able to calculate resistance.

- Students are able to apply Ohm's Law

Series and Science

parallel

circuit

Voltage

and

current measurem ent

- Students are able to recall a resistor, diode, and battery as an electrical component.

- Students are able to recall the principle of series and parallel circuit

\section{Technology}

- Students are able to identify the part of YWRobot.

- Students are able to identify Arduino Uno

\section{Engineering}

- Students are able to construct series and parallel circuit with YWRobot.

- Students are able to use multimeter appropriately.

3. Arduino 1. Draw the scheme of the circuit in the

\section{Parallel Technology}

circuit

- Students are able to identify the port of Arduino Uno.

- Students are able to identify Arduino software

\section{Engineering}

- Students are able to construct a traffic light circuit by using Arduino Uno 
a multimeter to measure current and voltage. Afterward, the students are challenged to construct a combined seriesparallel circuit with three lamps. If the students fail to light on three lamps, they have to check the arrangement of resistor and lamps into a negative or positive pole in a protoboard, re-arrange and reconstruct the circuit.

While in the third meeting the students are challenged to develop their ideas to construct a parallel circuit with three lamps which connect to Arduino Uno. Students have to test their construction by connecting the circuit to the laptop and if their lamps failed to glow after inputting the formulae through Arduino software, they had to evaluate whether they failed to connect the wire to GND (ground) or to the digital pit in Arduino Uno. After the students found their failure, they had to re-design and re-construct their circuit.

\section{Focus on Daily Life and Environmental Phenomenon}

In the third meeting, the students are required to make a project which relates to electricity. The traffic light project was considered to relate to the topic of electricity and near to daily life phenomenon. After using YWrobot in the second meeting, in this meeting the students are required to use a more advanced electrical component such as Arduino Uno.

\section{STEM Learning Lesson Plan Implementation}

The implementation of STEM Learning was conducted within three meetings, it included pretest and posttest. This research was conducted between Aprils - May 2017 in one of the Private Junior High School in Bogor Regency with the $8^{\text {th }}$-grade students as the sample.

In implementing this learning approach, the observation was conducted to check the whole learning activity whether it is consistent with the steps which written in the lesson plan or not. The template of the observation sheet for three meetings was the same, but the sequence of STEM Learning activity is different. It was made based on every lesson plan constructed by the author. The score of observation can be gained from the result of the observer. There were two check mark, "yes" and "no". "Yes" was written, if during observation the observer found the learning activity was done completely. While "No" was written if during observation the observer found the learning activity was done incompletely. There was column provided to write the additional description or comments related to the observation.

The observation sheet was given to $8^{\text {th }}$-grade physics teachers before class activity begin. The teachers stayed in the class and observed the learning activity conducted by both teacher and students in every meeting.

The full format of the observation sheet can be accessed in the attachment. The result of the observation sheet, include the sequence of STEM Learning activity are shown in Table 3.

According to the observation result from the physics teacher, the implementation of STEM Learning was
Table 5 Students' response percentage of games science worksheet (introduction)

\begin{tabular}{llccc}
\hline No & \multicolumn{1}{c}{$\begin{array}{c}\text { Question } \\
\text { Total Students: 16 }\end{array}$} & $\begin{array}{c}\text { \% } \\
\text { Correct }\end{array}$ & T & F \\
\hline 1 & $\begin{array}{l}\text { How is currently produced } \\
\text { in this circuit? }\end{array}$ & 87.5 & 14 & 2 \\
2 & $\begin{array}{l}\text { Is there any resistor in that } \\
\text { circuit what is the function } \\
\text { of resistor? }\end{array}$ & 75 & 12 & 4 \\
3 & $\begin{array}{l}\text { How does Ohm's law } \\
\text { mention about the circuit? }\end{array}$ & 100 & 16 & - \\
$4 \quad \begin{array}{l}\text { What are the differences } \\
\text { between series and parallel } \\
\text { circuit? }\end{array}$ & 25 & 4 & 12 \\
$5 \quad \begin{array}{l}\text { How do you calculate the } \\
\text { resistance of series and } \\
\text { parallel circuit? }\end{array}$ & 100 & 16 & - \\
Average & 77.5 & 12.5 & 3.6 \\
\hline
\end{tabular}

applied almost completely. The first meeting was considered as less complete because the researcher couldn't able to run the time management effectively. Therefore the class ended without any conclusion and the step of introduction to YWrobot and Arduino is missed. Therefore, the first meeting obtains $83 \%$. While the rest of the learning activity in the second and third meeting is run adequately.

\subsection{Worksheet Applied To STEM Learning}

\section{Constructing STEM Learning Worksheet}

Besides developing a lesson plan, the worksheet is constructed as a compliment for delivering the procedure regarding the experiment and assessing students' work. As well as a lesson plan, the worksheet is developed through learning objective the topic of electricity as stated in Chapter II; Electricity developed STEM Literacy and learning activity (experiment) which adjusted with STEM Learning written in the lesson plan.

There are three worksheets used for three meetings. As well as a lesson plan, each worksheet used belongs to one lesson plan and emphasize a certain aspect of STEM Literacy. The full version of three worksheets is available in the attachment. While the content summary of each worksheet and its relation with developed STEM Literacy are described in Table 4.

It can be seen from Table 4 that every question in the worksheet is constructed coherently with the experiment conducted by the students. Therefore the teacher can assess students' understanding of electricity and students' performance regarding the experiments. Moreover, those three worksheet emphasizes certain STEM Literacy aspects in each meeting.

After constructing worksheet as mentioned in the previous explanation, the three worksheets are used in three meetings. The usage of each STEM Learning worksheet regarding its experiment is described as follow; 

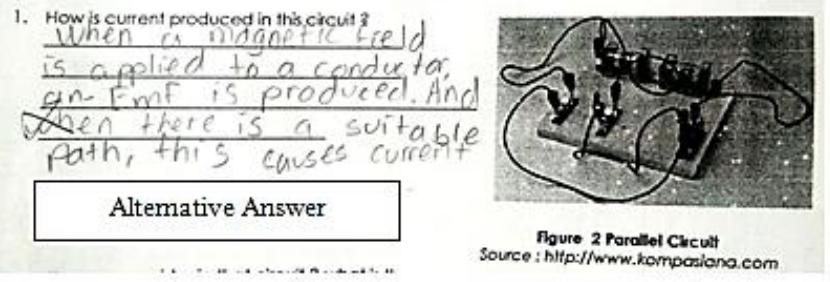

1. How is cunent produced in this crevit ? it is produced by a flow of electrons.

$$
\frac{V}{\text { Expected Answer }}
$$

Figure 4 Students' answer (No.1)

\section{MGames Science Worksheet}

The use of MGames Science is the main activity in the first meeting, therefore this worksheet use as a complement to engage students' with MGames Science. It can be seen from the type of questions. Question 1-5 delivered as an introduction to recall students' previous topic about basic electricity before using MGames Science. If the students forget about the basic topic of electricity, students might answer those five questions by opening "Learn about Circuit" page in MGames Science. The students' response regarding the questions is tabulated in Table 5.

Most of the students answer the question 1 correctly but there is a student who has a different understanding about the current flow. Even in the worksheet, there is no magnet and magnetic field figure, but the student relates the question "How is currently produced in this circuit (parallel circuit)" with magnetic field concept. Therefore question number 1 have answered correctly by $87.5 \%$ students. The expecting and the alternative answers of the students can be seen in Figure 4.

$75 \%$ of students answered the second question correctly, but there are several students who have alternative answers. Those students considered LED as

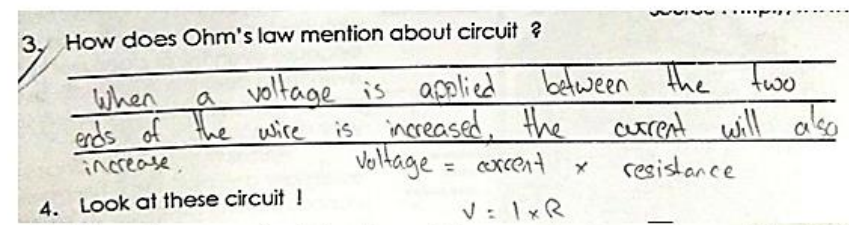

5. How do you calculate the resistance of series and parallel circuit ?
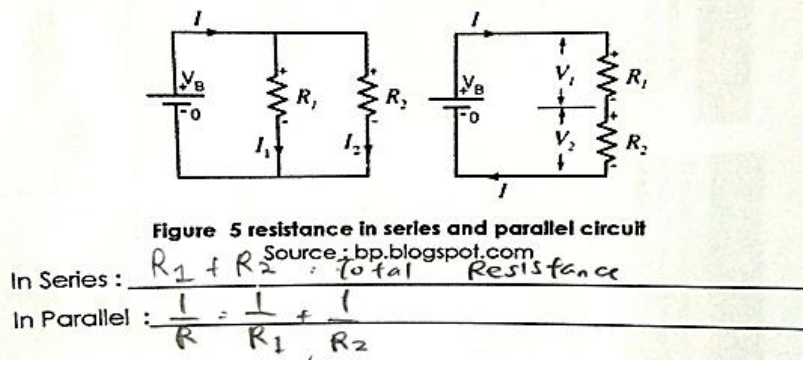

Figure 6 Students' answer (No. 3 and 5)

DOI: 10.17509/jsl.v1i3.11789

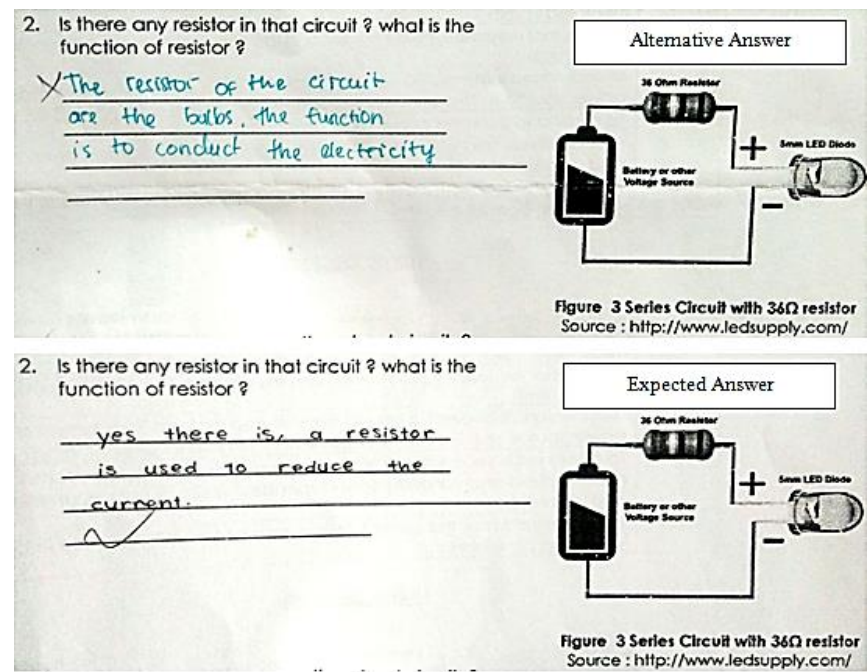

Figure 5 Students' answer (No.2)

one of the resistors to conduct the electricity. Both right and alternative answers of students can be explained in Figure 5.

Question number 3 and 5 reach $100 \%$ correct, it is because Ohm's Law and series-parallel resistance formula were learned frequently by the students in the physic class. Therefore the students can answer those questions correctly. The students' answer to both questions is shown in Figure 6.

Question number 4 have the lowest achievement from other questions, $25 \%$. It happened because most of the students don't understand clearly the main point of question number 4. But there are students who can differentiate the circuit through the voltage and the current flow. The differences between alternative and expected answers from the students are shown in Figure 7.

The second part of the worksheet is adopted from MGames Science. It consists of four stage with five level in every stage. Since students' work on MGames Science can't

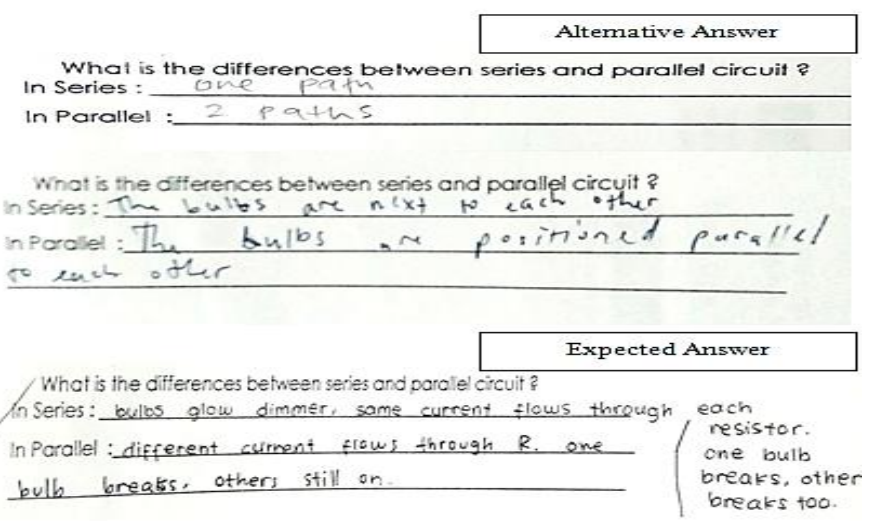

Figure 7 Students' answers (No. 4) 
Table 6 Students' response percentage of mgames science worksheet (part 2)

\begin{tabular}{|c|c|c|}
\hline No & $\begin{array}{l}\text { Questions } \\
\text { Total Students : } 16\end{array}$ & $\begin{array}{l}\text { Correct } \\
\text { Cor }\end{array}$ \\
\hline \multicolumn{3}{|c|}{ Stage one } \\
\hline 1 & Connect a single resistance in the circuit. Your circuit should have only the part & 100 \\
\hline 2 & Connect 4 resistance (anywhere) in a circuit. The circuit should have only one path. & 100 \\
\hline 3 & Connect the two given resistance in series. & 100 \\
\hline 4 & Draw and connect two resistors resistance in parallel. & 100 \\
\hline 5 & Connect the two given resistance in parallel. (Each resistance should be in a different path) & 87.5 \\
\hline \multicolumn{2}{|r|}{ Average } & 97.5 \\
\hline \multicolumn{3}{|c|}{ Stage Two } \\
\hline 1 & Each given resistance is of $10 \mathrm{ohms}$. Find the equivalent resistance of the circuit. (series) & 100 \\
\hline 2 & Each given resistance is of $10 \mathrm{ohms}$. Find the equivalent resistance of the circuit. (parallel) & 100 \\
\hline 3 & $\begin{array}{l}\text { The purple resistance is of } 12 \mathrm{ohms} \text { each and the blue one is of } 6 \mathrm{ohms} \text {. Find the equivalent } \\
\text { resistance of the circuit. }\end{array}$ & 100 \\
\hline 4 & $\begin{array}{l}\text { The purple resistance is of } 12 \mathrm{ohms} \text { each and the blue one is of } 6 \mathrm{ohms} \text {. Find the equivalent } \\
\text { resistance of the circuit }\end{array}$ & 100 \\
\hline 5 & $\begin{array}{l}\text { The purple resistance is of } 12 \mathrm{ohms} \text { each and the blue one is of } 6 \mathrm{ohms} \text {. Find the equivalent } \\
\text { resistance of the circuit }\end{array}$ & 100 \\
\hline \multicolumn{2}{|r|}{ Average } & 100 \\
\hline \multicolumn{3}{|c|}{ Stage Three } \\
\hline 1 & Connect five resistance ( $10 \mathrm{ohms}$ each) to get an equivalent resistance of $50 \mathrm{ohms}$. & 100 \\
\hline 2 & Connect two resistance of $10 \mathrm{ohms}$ to get an equivalent resistance of $5 \mathrm{ohms}$. & 100 \\
\hline 3 & Connect three resistance $(6 \mathrm{ohms}$ each to get an equivalent resistance of $2 \mathrm{ohms}$. & 100 \\
\hline 4 & Connect 3 resistance ( $6 \mathrm{ohms}$ each) to get an equivalent resistance of $4 \mathrm{ohms}$. & 100 \\
\hline 5 & Connect 5 resistance ( $6 \mathrm{ohms}$ each) in a circuit to get an equivalent resistance of $5 \mathrm{ohms}$. & 100 \\
\hline \multicolumn{2}{|c|}{ Average } & 100 \\
\hline \multicolumn{3}{|c|}{ Stage Four } \\
\hline 1 & $\begin{array}{l}\text { A battery of } 6 \text { volts is connected connect the given resistance in the circuit and find the current } \\
\text { through the circuit using Ohm's Law }\end{array}$ & 100 \\
\hline 2 & $\begin{array}{l}\text { A battery of } 9 \text { volts is connected. Connect the given resistance in the circuit and find the current } \\
\text { through the circuit using Ohm's Law. }\end{array}$ & 100 \\
\hline 3 & $\begin{array}{l}\text { A current of two amperes is flowing through the circuit. Find the voltage of the battery using Ohm's } \\
\text { Law. }\end{array}$ & 100 \\
\hline 4 & Connect the two resistance in series and find the current flowing through the 12 -ohm resistance. & 100 \\
\hline 5 & Connect two resistance in series and find the current flowing through the 12-ohm circuit. & 100 \\
\hline \multicolumn{2}{|c|}{ Average } & 100 \\
\hline
\end{tabular}

be recorded, therefore adding the five level of every stage in the worksheet is aimed to assess students' work in using

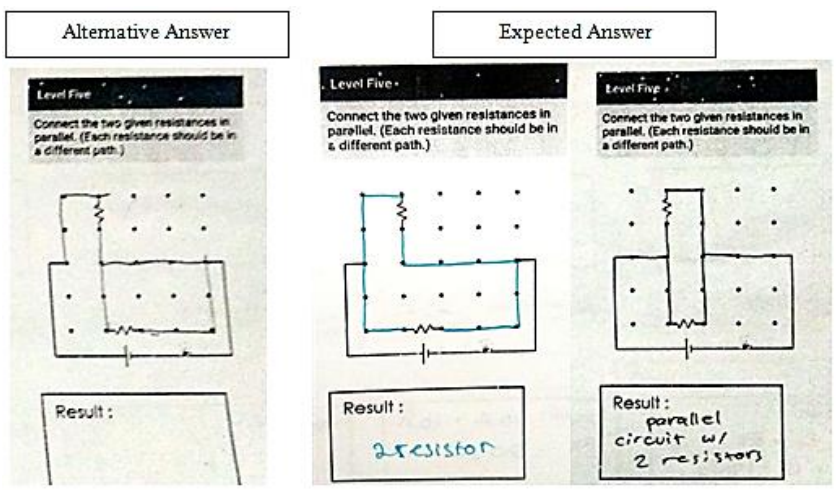

Figure 8 Students' answer (Level 5)
MGames Science easily. The students' response percentage are tabulated in Table 6 .

In the first stage, level 1- 4 questions are answered correctly by $100 \%$ students. This is because the level $1-4$ ask the students to draw the basic path of series and parallel which is very common for students. While for level 5 , there are students who fail to connect two resistors in a different path. Therefore this level is answered correctly by $87.5 \%$ of students. Both alternative and expected answers from students are shown in Figure 8.

The second stage of MGames Science is answered correctly by $100 \%$ students. All levels in the second stage ask the students to calculate the equivalent resistance in series and parallel which very common to the students. Therefore this stage is completely finished by the students as shown in Figure 9. 
Table 7 Students' answer percentage of YWrobot worksheet

\begin{tabular}{|c|c|c|c|c|}
\hline No & Questions & \multicolumn{3}{|c|}{$\begin{array}{l}\text { Correct } \\
\text { Total students: } 18\end{array}$} \\
\hline 1. & $\begin{array}{l}\text { Measuring Voltage and } \\
\text { Current in the Working } \\
\text { Circuit } \\
\text { (Series Circuit) }\end{array}$ & 67 & 12 & 6 \\
\hline 2. & $\begin{array}{l}\text { Measuring Voltage and } \\
\text { Current in the Working } \\
\text { Circuit } \\
\text { (Parallel Circuit) }\end{array}$ & 35 & 6 & 12 \\
\hline 3. & $\begin{array}{l}\text { Build your Own Circuit } \\
\text { (Series Circuit) }\end{array}$ & 100 & 18 & - \\
\hline 4. & $\begin{array}{l}\text { Build your Own Circuit } \\
\text { (Combined Series and } \\
\text { Parallel Circuit) }\end{array}$ & 67 & 12 & 6 \\
\hline \multicolumn{2}{|c|}{ Average } & 67.25 & 12 & 6 \\
\hline
\end{tabular}

The third and four stage are also answered correctly by $100 \%$ students. All levels in the third stage are almost the same with the second level, but the difference is the students are asked to draw circuit based on the equivalent resistance which stated in every level. While all levels in the four-stage are asked the students to apply Ohms' Law. Those two stages are represented in Figure 10 respectively.

According to the result, the first worksheet is almost 95\% finished correctly by all students. Since the content of the worksheet is about equivalent resistance and Ohm's Law which learned frequently by the students. Therefore,

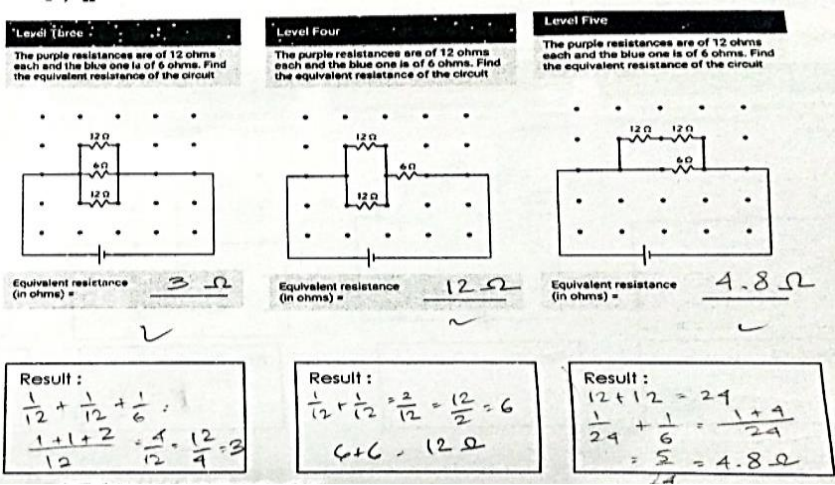

Figure 9 Students' answer (2nd Stage)

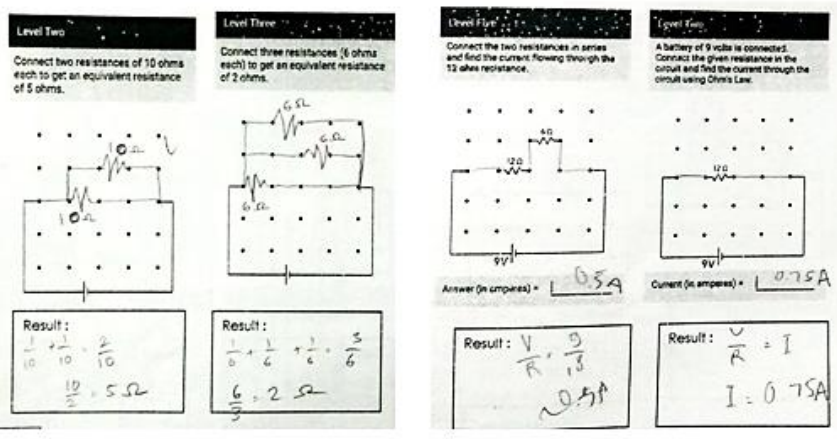

Figure 10 Students' answers (3rd and 4th Stage) this worksheet support students to apply science and math content.

\section{YWRobot Worksheet}

In the second meeting, the worksheet is used to help with the implementation of STEM Learning and develop science, technology, and engineering literacy. The worksheet consists of the steps as shown in Figure 11 to construct series and parallel circuit using YWRobot. Therefore, the worksheet guides the students' engineering design process and open-ended exploration.

There are some questions in the worksheet to assess students' work. The percentage of students' answer are tabulated in Table 7. In the first task, students are asked to measure the voltage and current of their series circuit by using a multimeter. This question is answered $67 \%$ correctly by the students. Most of the students are able to prove that the series circuit has different voltage and same current flow. While the rest of the students are not able to find completely the value of each voltage and current. Both alternative and correct answer of students are shown in Figure 12.

$35 \%$ of the students are correct in measuring voltage and current in a parallel circuit with a multimeter. The
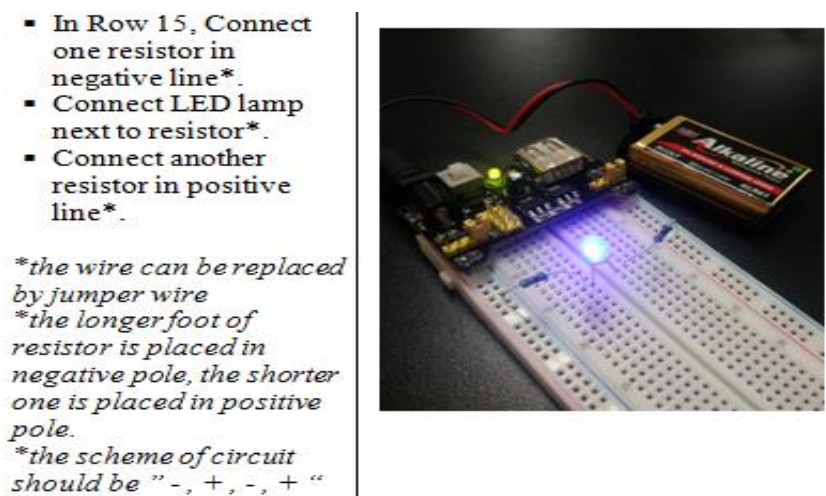

Figure 11 Part of YWRobot worksheet

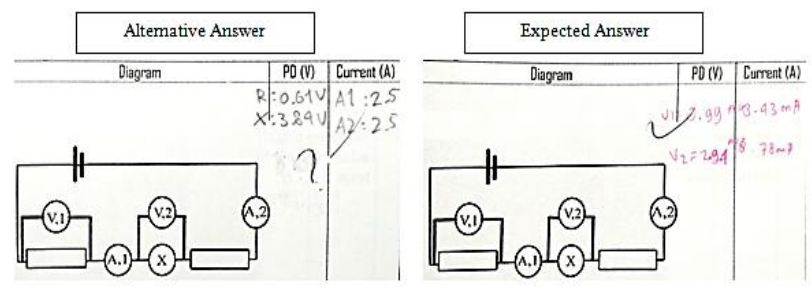

Figure 12 Students' answer (No.1)

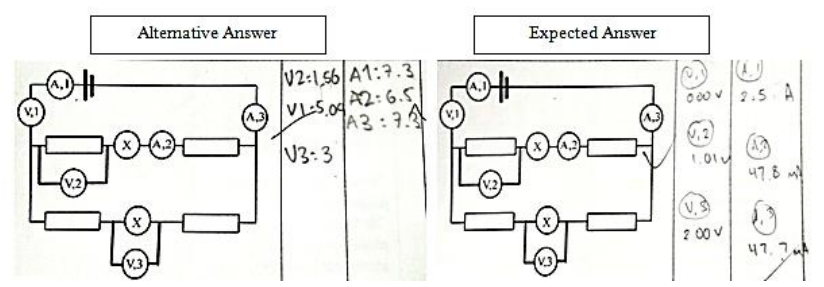

Figure 13 Students' answer (No.2) 
Table 8 Students answer percentage of Arduino Uno worksheet

\begin{tabular}{llccc}
\hline No & $\begin{array}{l}\text { Question } \\
\text { Total Students: 18 }\end{array}$ & $\begin{array}{c}\text { \% } \\
\text { Correct }\end{array}$ & T & F \\
\hline 1 & $\begin{array}{l}\text { Draw the scheme of the circuit } \\
\text { in the table. }\end{array}$ & 88 & 16 & 2 \\
$2 \quad \begin{array}{l}\text { Modify your own project and } \\
\text { write which part of the project } \\
\text { that has been modified. }\end{array}$ & 88 & 16 & 2 \\
Average & 88 & 16 & 2 \\
\hline
\end{tabular}

students find the correct range value of each voltage and current flow through the circuit. Moreover, students can prove that the parallel circuit has a different current flow and same voltage.

The rest of the students fail to find completely the value of voltage in the parallel circuit. The students' result as shown in Figure 13 of the voltage is far from the theory and correct range value.

The third and fourth questions ask the students to construct and draw schemes of the circuit. There is a series circuit with two lamps and combined series-parallel circuit with three lamps which should be constructed and drawn by the students. $100 \%$ of students answer the third question completely. This is because the figure is similar to a common series circuit which added with two lamps. The students' scheme is presented in Figure 14.

The next question is answered correctly by $67 \%$ of students. The rest of the students don't draw the correct scheme of the combined series-parallel circuit with three
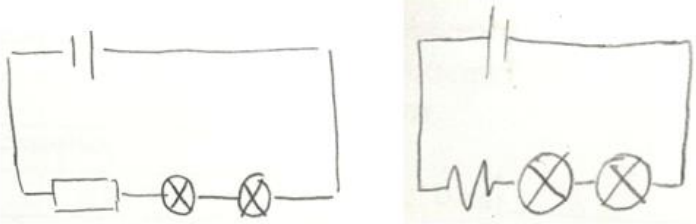

Figure 14 Series circuit scheme drawn by students
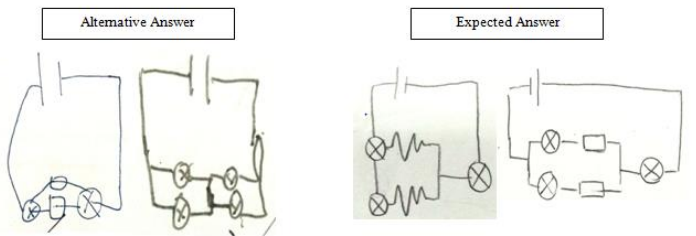

Figure 15 Combined circuit scheme drawn by students

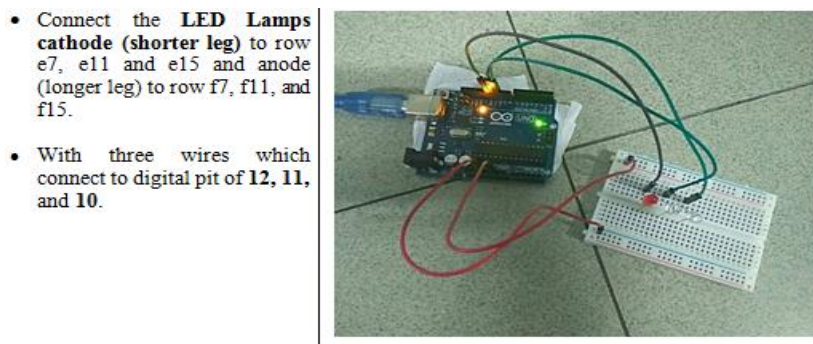

Figure 16 Part of Arduino Uno worksheet lamps. As shown as in Figure 15 students fail to draw two resistors which connected to one lamp.

According to the result, it can be stated that this worksheet is less finished correctly by students. It is because the result of the first and second questions are very influenced by the multimeter and how students operate it. It is also because human error can't be avoided in this experiment. Even the result is less complete, but this worksheet support students' open-ended exploration, recalling science concept of electricity, and the engineering design process in constructing a series-parallel circuit with YWRobot.

\section{Arduino Uno Worksheet}

The third worksheet is almost the same as the second worksheet. It is used to help the implementation of STEM Learning and developed Engineering and Technology Literacy. The third worksheet consists of the steps as shown in Figure 16 to lead the students in constructing a Traffic Light Project with Arduino Uno.

It is also added with two additional questions about traffic light circuit scheme and modifying traffic light to asses students' work. Students' response to those two questions is tabulated in Table 8 .

The first and second questions of the third worksheet are answered correctly by $88 \%$ students. The students can draw the symbol correctly to represent of Arduino Uno and traffic light circuit in parallel. The students are also able to explain their modification such as changing the resistor to the jumper wire, the color of the lamp, and inputting new "delayed time" of each lamp.

While the rest of the students draw an Arduino Uno as square next to the symbol of the power supply, it can be
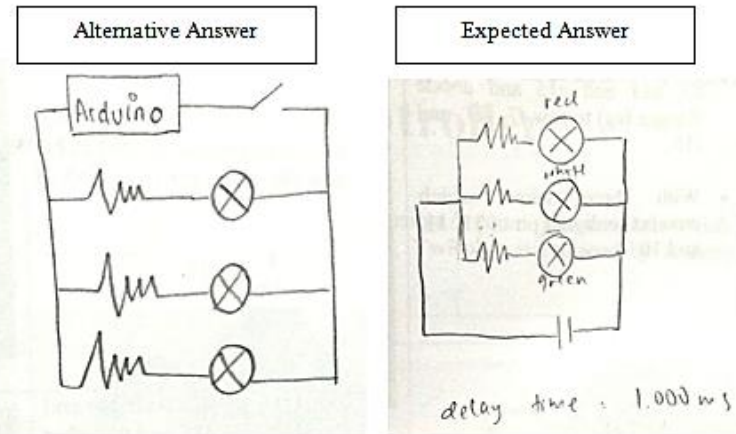

Figure 17 Traffic light circuit scheme drawn by students

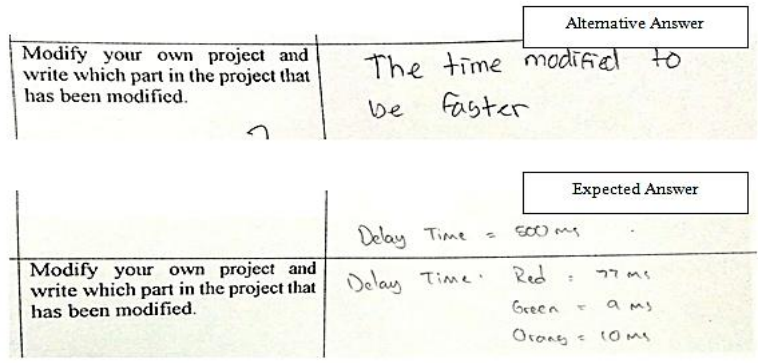

Figure 18 Students' answer 
Table 9 STEM Literacy based test analysis

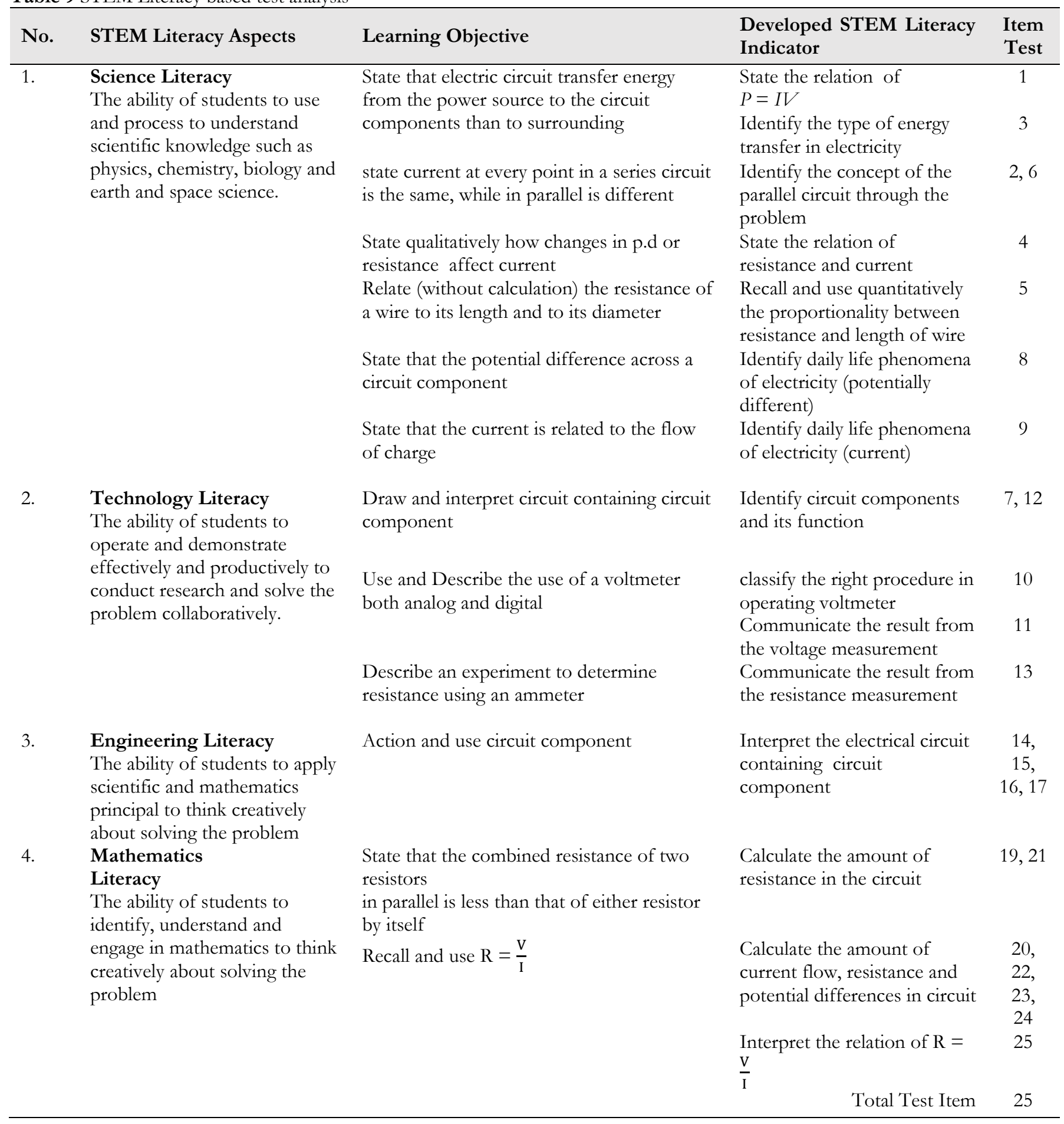

shown in Figure 17. In fact, Arduino Uno is not only used to save and drive the formula but also to control the voltage and current flow to the circuit.

In the modification of the circuit, the students fail to explain their modification completely. Several students only write the sentence such as "the time modified to be faster" as shown in Figure 18, without any additional information about the delayed time after is it modified.
According to the result, this worksheet is almost finished completely by the students. Moreover, this worksheet supports the students' open-ended exploration, recalling the science concept of electricity, and the engineering design process in constructing traffic light circuit with Arduino Uno. 
3.3 STEM Literacy Instrument Test Applied To STEM Learning

\section{Constructing STEM Literacy Based Test}

The main objective of STEM Learning implementation is the improvement of students' STEM Literacy. Therefore, STEM Literacy instrument test is constructed to evaluate students' STEM Literacy. STEM Literacy based test consists of questions that developed from learning objective of electricity topic and adjusted with four stands of STEM Literacy from Zollman (2012). The STEM Literacy instrument test consists of 25 questions about the topic of electricity learned by the students. The full version of test items is attached in the attachment. Thus, the relation between question content, learning objective of electricity topic and the strands of STEM Literacy are described in Table 9.

According to Table 9, it can be seen that each aspect of STEM Literacy distributes in questions separately. It is arranged separately to assess every aspect easily. Therefore, each question belongs to certain STEM Literacy aspects.

The Effect of STEM Learning on Students' STEM Literacy

The effect of students' STEM Literacy can be measured from the result of pretest and posttest. Both pre-test and post-test covered four aspects of STEM Literacy such as science, technology, engineering, and mathematics. Those four aspects were distributed in the questions which used as pre-test and post-test.

The result of pretest and posttest in this research are processed by using MS. Word Excel 2007 and SPSS Statistic version 17.0. Afterward, it is analyzed through a normality test, $t$-test paired sample test, and normalized gain. Those three analyses are described as follow:

Normality Test

Normality test is used to ensure whether the data is normally distributed or not. Normality test is also used to see whether the question in the test sides the higher

Table 10 Test of normality (one sample Kolmogorov Smirnov test)

\begin{tabular}{llrr}
\hline Details & & Post-test & Pre-test \\
& & $\mathbf{1 6}$ & $\mathbf{1 6}$ \\
\hline $\begin{array}{l}\text { Normal } \\
\text { Parameters, }\end{array}$ & Mean & 50.000 & 54.500 \\
& $\begin{array}{l}\text { Std. } \\
\text { Deviation }\end{array}$ & 13.54499 & 13.92360 \\
& Absolute & .191 & .146 \\
Most Extreme & Positive & .191 & .134 \\
Differences & Negative & -.191 & -.146 \\
& & .191 & .146 \\
Test Statistic & & $.602^{\mathrm{c}, \mathrm{d}}$ & $.883^{\mathrm{c}, \mathrm{d}}$ \\
Asymp. Sig. (2-tailed) & & \\
\hline
\end{tabular}

achiever students or lower achiever students. The result of the normality test is shown in the following Table 10 . According to the result in Table 10 both pretest and posttest from one sample Kolmogorov Smirnov the pvalue is 0.88 and 0.60 respectively, while the level significance (alpha) is 0.05 . It can be stated that both the pretest and posttest p-value is greater than the level significance (alpha) which means the data is normally distributed. Therefore, the result can be analyzed through a T-Test paired sample.

T-Test Paired Sample

T-test paired sample test is used to identify whether the hypothesis is rejected or accepted. The result of the T-test paired sample is shown in the following Table 11.

According to the result, the p-value is 0.06 , while the level of significance (alpha) is 0.05 . It can be stated that $\mathrm{H}_{0}$ is accepted. Thus the hypothesis of $\mathrm{H}_{1}$ is rejected, which can be concluded that there is no significant main difference between students' STEM Literacy after applying STEM Learning. It can be presumed that the data obtained did not work to prove the hypothesis. Occasionally, it requires a large sample to prove the relationship between two variables.

\section{Normalized Gain Result}

The normalize gain score of the students explained whether there was any improvement or not on students' STEM Literacy. The analysis of students' STEM Literacy is done not only in general result. The author has analyzed the four aspects of STEM Literacy such as science, technology, engineering, and mathematics. The aim of this analysis is to see the effect of STEM Learning toward students' STEM Literacy (per aspects). The result of pretest and posttest of students' and the N-gain score of STEM Literacy in general and each aspect is shown in Table 12.

Based on Table 12, the result of pretest is good enough but there was decreasing in the post-test score. According to interview with the physic teacher which held on Tuesday, 13 th of June 2017, the students could get that average score because they have already got the topic of electrical quantities and circuits in the previous meeting. Therefore the students could recognize the topic well.

While for the post-test, the teacher added that in the meeting when the students got post-test, they have passed the formative test in the previous week. Since in the formative test they had to answer a lot of type questions

Table 11 Result of t-test paired sample

\begin{tabular}{lcc}
\hline Details & Pre-test & Post Test \\
\hline Mean & 54.5 & 50 \\
Mean of Differences & -4.5 \\
Standard Deviation of Difference & \multicolumn{2}{c}{8.98} \\
Standard Error of Difference & 2.24 \\
T count & 2.002 \\
Upper Confidence Level & \multicolumn{2}{c}{9.28} \\
Lower Confidence Level & -0.28 \\
Significance (2-tailed) & \multicolumn{2}{c}{0.06} \\
\hline
\end{tabular}


Table 12 Result of pre-test and post-test STEM literacy

\begin{tabular}{|c|c|c|c|c|c|c|c|}
\hline \multirow[b]{2}{*}{ No } & \multirow{2}{*}{$\begin{array}{c}\text { Aspects of } \\
\text { STEM Literacy }\end{array}$} & \multirow[b]{2}{*}{ Question content } & \multirow[b]{2}{*}{ Item Test } & \multicolumn{2}{|c|}{ Score } & \multirow[b]{2}{*}{$<\overline{\boldsymbol{g}}>$} & \multirow[b]{2}{*}{ Category } \\
\hline & & & & $\begin{array}{l}\text { Pre- } \\
\text { test }\end{array}$ & $\begin{array}{l}\text { Postt } \\
\text { est }\end{array}$ & & \\
\hline 2. & $\begin{array}{l}\text { Science } \\
\text { Literacy }\end{array}$ & $\begin{array}{l}\text { Electrical Quantities : } \\
\text { - Power in an electric circuit } \\
\text { - Current in a parallel circuit } \\
\text { - Type of energy transfer in electricity } \\
\text { - Current in a series circuit } \\
\text { - The relation between the resistance of a } \\
\text { wire to its long and diameter } \\
\text { - Daily life phenomena of electricity; } \\
\text { potential difference and current }\end{array}$ & $\begin{array}{c}1,2,3,4,5 \\
6,8,9\end{array}$ & 4.06 & 4 & -0.06 & Low \\
\hline 4. & $\begin{array}{l}\text { Engineering } \\
\text { Literacy }\end{array}$ & $\begin{array}{l}\text { Electric circuit : } \\
\text { - Electrical working circuit containing } \\
\text { circuit components. }\end{array}$ & $\begin{array}{c}14,15,16 \\
17\end{array}$ & 2.25 & 2.18 & -0.06 & Low \\
\hline 5. & $\begin{array}{l}\text { Mathematics } \\
\text { Literacy }\end{array}$ & $\begin{array}{l}\text { Electrical Quantities : } \\
\text { - Resistance in parallel circuit } \\
\text { - The equation of } V=I \times R\end{array}$ & $\begin{array}{l}18,19,20 \\
21,22,23 \\
24,25\end{array}$ & 4.25 & 3.37 & -0.87 & Low \\
\hline
\end{tabular}

not only about electrical quantities and circuit but also magnetism and electromagnetic effect, therefore it can be stated that they might forget about the topic of electricity which has been learned in the early meetings. Another factor came from the time lag of each meeting. One of the factors which influence students' achievement is the continuation of certain approach implementation. Based on the academic calendar the first meeting was conducted on week 17, the second meeting was conducted on week 19 and the last meeting was conducted on week 21 . Because of that time lag, the continuation of STEM Learning implementation run less optimally. Therefore, it is not able to strengthen students STEM Literacy on the topic of electricity.

Specifically, the analysis of the effect of STEM Learning toward students' STEM Literacy (per aspects) regarding the result of STEM Literacy test are described as follow.

Students' Science Literacy Analysis

From the Table 12, it can be seen that science literacy aspect of students has the value of -0.06 in average normalized gain. If it is compared to the result of pre-test and post-test, that value is categorized as low because there was no improvement but decreasing the score of post-test.

There are several factors which caused the decreasing of students' posttest score, especially in the science literacy aspect. From the physic teacher who observes the class during teaching-learning process that has been interviewed on $13^{\text {th }}$ June 2017, the teacher assumed the content of electricity was repeated very well in the first meeting, the use of MGames Science were able to strengthen students mastery. In the second meeting, the series and parallel circuit construction were delivered well, but the use of multimeter in measuring voltage and current was less emphasized to the students. For the last meeting the using of Arduino Uno was an attractive learning activity, but in fact, Arduino Uno seemed like another part of electricity. It can be very seen in the third meeting, Arduino Uno was good to develop electricity insight of the students but less suitable to strengthen students understanding of electricity topic.

It can be concluded that STEM Learning implementation was conducted less optimal to improve the science literacy of students. The science literacy of students is still low due to the learning process couldn't emphasize the concept of current, voltage and resistance well to the students. On the contrary, the learning process focused on the students on YWrobot and Arduino Uno experiments.

In line with previous research Afriana, Permanasari \& Fitriani (2016) argued that low achievement of student's science literacy is caused by the PjBL STEM implementation which runs less optimal. This learning process makes students tend to more focus on a final project to finished at a given time. Therefore science concepts are less emphasized during the lesson (Afriana, Permanasari \& Fitriani, 2016). In Another research from Septiani (2016) stated that the implementation of STEM 
Learning approach is not quite successful to drive students in analyzing the relation between each subtopic, therefore the students have difficulties in applying science concept. Septiani (2016) also added that the STEM Learning approach needs to implement continuously to improve science process skill and cognitive of the students.

Students' Technology Literacy Analysis

Technology literacy aspect of students has the value of -0.12 in average normalized gain which categorized as low. Nevertheless, the implementation of STEM Learning in three meeting require students to use MGames Science application on the android phone and electrical components in second and third meeting which purpose to engage students with the technology and its appliances. But, presumably, it can't increase the technology literacy of students optimally due to the experiment is done only in one meeting for each experiment. Therefore, several detailed explanations about the incoherent result of measurement, an obstacle in using the instrument and translating the result regarding the experiment are not explained deeply.

The previous research from Supahar \& Istiyono (2015) stated that the STEM approach in physics subject is less appropriate to improve technology literacy of the students. Even the students are good in planning the steps of measurement experiment, they still have difficulties to take the data through correct measurement, read the result of measurement, and analyze the result from the instrument used (Supahar \& Istiyono, 2015). There is another factor which causes low achievement of student's technology literacy. Avsec \& Jamsek (2016) stated that students in grade 7-9 at Slovenian secondary school perform poorly on the technology literacy test because technology education is not sufficiently included in schools curriculum. The school should provide the optional subject of technology education such as electronic or robotic to foster active learning and problem solving with the implementation of the problem and project-based learning. Therefore the dimension of technology literacy such as technical knowledge, technical capacity, and critical thinkingdecision making can be achieved optimally by the students (Avsec \& Jamsek, 2016).

Students' Engineering Literacy Analysis

It can be seen from the Table 12 that engineering literacy aspect of students has the value of -0.06 in average normalized gain, which means it is categorized as low. Even the usage of YWrobot and Arduino Uno in second and third meetings required students to design, construct, and test and evaluate their circuits. Nevertheless, the main objective of engineering literacy such as engaging the students with the engineering design process can't be achieved greatly by the students. Therefore, it cannot improve students engineering literacy optimally. In line with technology literacy, it can be presumed that the low achievement of engineering literacy is caused by the experiment is done only in one meeting for each experiment. The construction and the design of the electrical circuit containing the circuit component regarding YWrobot and Arduino Uno experiment can't be evaluated deeply.

Frequency in studying science with STEM Learning approach is one of the factors which affects students engineering literacy. According to Grunert and Adams (2016), engineering literacy of students (non-engineering students) can be improved for at least one semester. The students need to be introduced and engaged in the engineering design process through practice with experiment, design thinking, and analysis in sufficient time. McFarland, et al., (2017) stated that the American $8^{\text {th }}$ grade students who experience engineering design process through figuring out "why something was not working in order to fix it" and "taking something apart in order to fix it or see how it works "in science task more than five times have greater scale score (one domain of engineering literacy which is design-system related activity) than the students who experience one or twice that activity. Therefore, the time used to involve and engage students in the engineering design process will affect their engineering literacy.

Students' Mathematics Literacy Analysis

Mathematics literacy of the students has the lowest rank from other aspects of STEM Literacy. Mathematics literacy of the students has the value of -0.87 . There are a lot of decreasing from pre-test to post-test. From the discussion of the STEM Learning in the first, second and third meeting, it can be seen that mathematics literacy was only developed in the first meeting. In the first meeting the students required to calculate the resistance, voltage, and current in the certain circuit which provided in the MGames Science. While in the next meeting, the students are concerned to develop technology and engineering literacy, and a few parts of science literacy. Therefore, it can be stated that mathematics and science literacy are less emphasized in those two meetings, and it makes the score of mathematics and science literacy decrease.

In line with others literacy aspects, mathematics literacy of students can't be developed directly in only one meeting. It needs sufficient time to make students understand the structure and the symbol of formulae and its relation with a certain concept. Leibowitz (2016) argued that Mathematical literacy of the students can be improved in at least two months. It is included the introduction and general overview which can support students mathematics literacy. Another point is a time lag which influences the continuation of STEM learning implementation in the class, each aspect of STEM literacy can't be developed and emphasized optimally. According to Supardi (2012), students must study certain concept related to mathematics continuously, because the previous concept will affect how students accept and understand the following concept. 
Therefore, the frequency-time which allows students to study will affect their literacy.

\section{CONCLUSION}

The finding showed that STEM Learning on Electricity using Arduino-Android Game Based Experiment has improved STEM Literacy by $-0.06,-0.12,-0.06,-0.87$ for Science, Technology, Engineering, and Mathematics Literacy respectively. Although the learning can adequately improve Technology and Engineering Literacy which categorized as low and fair. According to findings, several investigations have been analyzed based on the lesson plan, worksheet, and STEM Literacy based test. The brief conclusion is described as follow. The lesson plan which used in three meetings was constructed to have the characteristic of STEM Learning. Even the step of introducing YWRobot and Arduino Uno in the first meeting is missed, but the rest of the learning activity which started in three lesson plan were conducted adequately in the class.

There are three worksheets used as a compliment in STEM Learning implementation. MGames Science worksheet is finished correctly by $95 \%$ students. YWrobot worksheet is finished correctly by $67 \%$ students. The last Arduino Uno worksheet is finished correctly by $88.8 \%$ students. According to pre-test and post-test average in every sub-aspects of STEM Literacy, STEM Learning implementation was less able to improve students science, mathematics literacy, engineering, and technology literacy of the students. In addition, STEM Learning implementation was conducted in only three meetings and discontinuously. Therefore, science, technology, engineering, and technology literacy regarding electricity topic are emphasized less optimally.

\section{ACKNOWLEDGMENT}

The authors acknowledge the principal, teachers, and students of School of Madania, Bogor, Indonesia.

\section{REFERENCES}

Afriana, J., Permanasari, A., \& Fitriani, A. (2016). Project Based Learning Integrated to STEM to Enhance Elementary School's Students Scientific Literacy. Jurnal Pendidikan IP A Indonesia, 261-267.

Anwari, I., Yamada, S., Unno, M., Saito, T., Suwarma, I. R., Mutakinati, L., \& Kumano, Y. (2015). Implementation of authentic learning and assessment through stem education approach to improve students' metacognitive skills. K-12 STEM Education, 1(3), 123-136.

Avsec, S., \& Jamšek, J. (2018). A path model of factors affecting secondary school students' technological literacy. International Journal of Technology and Design Education, 28(1), 145-168.

Bybee, R. W. (2013). The Case for STEM Education: Challenges and Opportunities. Arlington, Virginia: NSTA Press.

Cambridge International Examinations. (2013). Cambridge IGCSE Physics Syllabus. United States: Board Examination Systems (BES) Pilot.

Cao, Y., \& Brizuela, B. M. (2016). High school students' representations and understandings of electric fields. Physical Review Physics Education Research, 12(2), 020102

Carro, G., Castro, M., Sancristobal, E., Diaz, G., Mur, F., Latorre, M., . . . Giller, D. (2014). The Color of The Light: A Remote Laboratory that uses A Smart Device that Connects Teachers and Students. Istanbul: IEEE Global Engineering Education Conference (EDUCON).

Creswell, J. W. (2012). Educational Research (Fourth Edition ed.). Boston: Pearson.

Creswell, J. W. (2012). Educational research: planning, conducting, and evaluating quantitative and qualitative research. Boston: Pearson Education, Inc.

Fraenkel, J., Wallen, N., \& Hyun, H. (2011). How to Design and Evaluate Research in Education. New York: McGraw Hill.

Fundoino. (2016). Tutorial For Arduino. Fundoino Service Team.

Grunert, J., \& Adams, D. S. (2016). Increasing Engineering Literacy among Non-Engineering Students. 2016 ASEE Annual Conference \& Exposition (pp. 1-13). New Orleans, Louisiana: ASEE PEER.

Huang, B. (2015). Open-source Hardware - Microcontrollers and Physics Education - Integrating DIY Sensors and Data. Washington: ASEE PEER.

Jolly, A. (2014). Six characteristics of a great STEM lesson. Education Week. Laboy-Rush, D. (2011). Integrated STEM Education through Project Based Learning. Portland, United States of America: Sematinticscholar.org.

Leibowitz, D. (2016). Supporting Mathematical Literacy Development: A Case Study of the Syntax of Introductory Algebra. Interdisciplinary Undergraduate Research Journal, 7-13.

Lou, S.-J., Shih, R. C., Diez, C. R., \& Tseng, K. H. (2011). The impact of problem-based learning strategies. International Journal Technology and Education, 21, 195-215.

McFarland, J., Hussar, B., Brey, C. d., Snyder, T., Wang, X., WilkinsonFlicker, S., . . . Hinz, S. (2017). The Condition of Education 2017. Washington DC: U.S. Department of Education.

Meluso, A., Zheng, M., A, H., \& Lester, J. (2011). Enhancing 5th graders' science content knowledge and self-efficacy through game-based learning. Computer \& Education, 487-504.

Monk, S. (2010). 30 Arduino Projects for The Evil Genius. New York: Mc Graw Hill.

Mulhall, P., McKittrick, B., \& Gunstone, R. (2001). A Perspective on the Resolution of Confusions in the Teaching of Electricity. Research in Science Education, 31, 575-587.

National Research Council (2013). Monitoring Progress Toward Successful K12. A Nations Advancing?. Washington, DC: National Academies Press.

Ong, F., Mclean, J., \& Greco, J. (2014). INNOVATE A Blueprint for Science, Technology, Engineering, and Mathematics in California Public Edu. California: California Department of Education.

Prima, E. C., Oktaviani, T. D., \& Sholihin, H. (2018). STEM learning on electricity using Arduino-phet based experiment to improve 8th grade students' STEM literacy. Journal of Physics: Conference Series, 1013(1), 012030

Prima, E. C., Putri, A. R., \& Rustaman, N. (2018). Learning Solar System Using PhET Simulation to Improve Students' Understanding and Motivation. Journal of Science Learning, 1(2), 60-70.

Prima, E. C., Putri, C. L., \& Sudargo, F. (2017). Applying Pre and Post Role-Plays supported by Stellarium Virtual Observatory to Improve Students' Understanding on Learning Solar System. Journal of Science Learning, 1(1), 1-7.

Rapini, S. (2012). Beyond Textbooks and Lectures: Digital Game-Based Learning. McLean, Virginia: Texas A\&M Bush School of Government and Public Service.

Reeve, E. M. (2013). Implementing Science, Technology, Mathematics, and Engineering (STEM) Education in Thailand. Logan, Utah: The Institute for the Promotion of Teaching Science and Technology (IPST).

Samsudin, A., Suhandi, A., Rusdiana, D., Kaniawati, I., \& Costu, B. (2016). Investigating the effectiveness of an active learning basedinteractive conceptual instruction (ALBICI) on electric field concept. Asia-Pacific Forum on Science Learning and Teaching, 17(1).

Septiani, A. (2016). Penerapan Asesmen Kinerja dalam Pendekatan Stem (Sains Teknologi Engineering Matematika) untuk Mengungkap Keterampilan Proses Sains. Seminar Nasional Pendidikan dan Saintek 2016, 654-659. 
Supahar, \& Istiyono, E. (2015). Pengembangan Asesmen Kinerja Berbasis STEM untuk. Meningktakan Soft Skill dan Hard Skill Peserta Didik Pada Pembelajaran Fisika SMA. Yogyakarta: Eprints Universitas Negeri Yogyakarta.

Supardi. (2012). Peran Berpikir Kreatif dalam Proses Pembelajaran Matematika. Formatif: Jurnal Ilmiah Pendidikan MIP A, 248-262.
Suwarma, I. R., Astuti, P., \& Endah, E. N. (2015). Balloon Powered Car As A STEM - Based Science Teaching Media. Prosiding Simposium Nasional Inovasi dan Pembelajaran Sains 2015, 373-376.

Tseng, K.-H., Chang, C.-C., Lou, S.-J., \& Chen, W.-P. (2013). Attitudes towards science, technology, engineering. International Journal of Technology and Education, 23, 87-102.

Zollman, A. (2012). Learning for STEM Literacy: STEM Literacy for Learning. School Science and Mathematics, 112, 12-19. 